\title{
Constituents with Radical Scavenging Effect from Opuntia dillenii: Structures of New $\alpha$-Pyrones and Flavonol Glycoside
}

\author{
Yingkun Qiu, ${ }^{a}$ Yingjie Chen, ${ }^{a}$ Yupin PeI, ${ }^{a}$ Hisashi MatsudA, ${ }^{b}$ and Masayuki YoshiKawA $*, b$ \\ ${ }^{a}$ Shenyang Pharmaceutical University; Shenhe-ku, Shenyang 110016, China: and ${ }^{b}$ Kyoto Pharmaceutical University; \\ Misasagi, Yamashina-ku, Kyoto 607-8412, Japan. Received June 26, 2002; accepted August 13, 2002
}

\begin{abstract}
The aqueous ethanolic extract from the fresh stems of Opuntia dillenii Haw. showed potent radical scanvenging activity. Three new compounds, opuntioside I, 4-ethoxyl-6-hydroxymethyl- $\alpha$-pyrone, and kaempferol 7-O- $\beta$ D-glucopyranosyl-( $1 \rightarrow 4)$ - $\beta$-D-glucopyranoside, were isolated from the extract. The structures of the new compounds were determined on the basis of chemical and physicochemical evidence and the radical scavenging effects of principal constituents were examined.
\end{abstract}

Key words Opuntia dillenii; radical scavenging effect; opuntioside I; 4-ethoxyl-6-hydroxymethyl- $\alpha$-pyrone; kaempferol 7-O- $\beta$ D-glucopyranosyl-( $1 \rightarrow 4)$ - $\beta$-D-glucopyranoside

Opuntia dillenii (Ker-Gaw.) Haw. is a cactus that grows mainly in the south of China and is called Xian Ren Zhang (仙人掌) in Chinese. The stem of this plant is used as a folk medicine for the treatment of diabetes, gastric ulcer, inflammatory and several other diseases, while its reddish fruit is commonly used as a coloring agent for foods, drinks and drugs. As chemical constituents of this plant, we previously isolated the flavonols such as quercetin, 3-O-methyl quercetin, kaempferol, kaempferide, and isorhamnetin and $\beta$ sitosterol from the stems. ${ }^{1}$ In our continuing study on the chemical constituents of $O$. dillenii, we found that the aqueous ethanolic extract showed potent radical scavenging effect. From the extract, three new compounds (2-4) were isolated together with 14 known compounds. In this paper, we report the isolation and structure elucidation of new compounds as well as the radical scavenging effect of the principal constituents.

The $80 \%$ aqueous ethanol extract from the fresh stems of $O$. dillenii, which were collected on the beach of Hainan province of South China, was separated by the procedure shown in Chart 1; that is, it was partitioned into a chloroform and water mixture. The aqueous phase was further extracted with 1-butanol. The 1-butanol-soluble phase was subjected to silica gel column chromatography to give seven fractions. As is apparent from Chart 1, each fraction was subjected to further separation using repeated ODS, silica gel, Sephadex LH20 column chromatography, and HPLC to give opuntiol (1, $0.0032 \%),{ }^{2,3)} p$-hydroxybenzoic acid $(0.0023 \%)$, L-(-)-malic acid $(0.00019 \%)$, opuntioside I (2, 0.078\%), 3,3'-dimethylquercetin $(0.00019 \%),{ }^{4)}(E)$-ferulic acid $(0.00053 \%)$, 4 ethoxyl-6-hydroxymethyl- $\alpha$-pyrone $(3,0.00013 \%), 1$-heptanecanol $(0.0019 \%)$, vanillic acid $(0.00035 \%)$, isorhamnetin-3-O-rutinoside $(0.0070 \%),{ }^{5)}$ rutin $(0.00014 \%)$, kaempferol $\quad 7-O-\beta$-D-glucopyranosyl-( $1 \rightarrow 4)$ - $\beta$-D-glucopyranoside $(4,0.0001 \%), 3-O$-methyl quercetin $7-O-\beta$-D-glucopyranoside $(0.00015 \%),{ }^{6}$ kaempferol $7-O-\beta$-D-glucopyranoside $(0.00019 \%),{ }^{7)}$ manghaslin $(0.003 \%),{ }^{8}$ ethyl 3,4-dihydroxybenzoate $(0.00014 \%)$, and 3,4-dihydroxybenzoic acid (0.00041\%).

Opuntioside I (2) was isolated as a colorless crystal with negative optical rotation $\left([\alpha]_{\mathrm{D}}^{20}-42.0^{\circ}\right)$. The IR spectrum of 2 showed absorption bands ascribable to hydroxyl and carbonyl functions at 3367 and $1703 \mathrm{~cm}^{-1}$. The positive-ion
FAB-MS of 2 showed a quasimolecular ion peak at $\mathrm{m} / \mathrm{z} 319$ $(\mathrm{M}+\mathrm{H})^{+}$. The molecular formula $\mathrm{C}_{13} \mathrm{H}_{18} \mathrm{O}_{9}$ was determined from the quasimolecular ion peak observed in the positive ion FAB-MS and by high-resolution FAB-MS analysis. The ${ }^{1} \mathrm{H}-\mathrm{NMR}\left(\mathrm{CD}_{3} \mathrm{OD}\right)$ and ${ }^{13} \mathrm{C}-\mathrm{NMR}\left(\mathrm{CD}_{3} \mathrm{OD}\right.$, Table 1$)$ spec$\operatorname{tra}^{9)}$ of 2 showed the presence of a methoxyl group [ $\delta 3.88$ $\left.\left(\mathrm{s}, 8-\mathrm{H}_{3}\right)\right]$, a methylene bearing an oxygen function $[\delta 4.48$, $\left.4.62\left(\mathrm{~d}, J=14.8 \mathrm{~Hz}, 7-\mathrm{H}_{2}\right)\right]$, two olefinic protons $[\delta 6.38(\mathrm{~m}$, $5-\mathrm{H}), 5.57$ (br s, 3-H)] together with a $\beta$-D-glucopyranosyl moiety $\left[\delta 4.37\left(\mathrm{~d}, J=7.5 \mathrm{~Hz}, 1^{\prime}-\mathrm{H}\right)\right]$.

Enzymatic hydrolysis of 2 with $\beta$-glucosidase in acetate buffer (pH 4.4) yielded opuntiol (1) as the aglycon. Acid hydrolysis of 2 with $1 \mathrm{M} \mathrm{HCl}$ in dioxane- $\mathrm{H}_{2} \mathrm{O}(1: 1)$ also liberated 1 and D-glucose, which was identified by HPLC analysis using optical rotation detection. ${ }^{10)}$ Comparison of the carbon chemical shifts in the ${ }^{13} \mathrm{C}$-NMR data for 2 with those for opuntiol (1) indicated a glycosidation shift around the 7-position of the opuntiol moiety. In the heteronuclear multiple bond connectivity (HMBC) spectrum, a long-range correlation peak was observed from the anomeric proton of substituted glucosyl moiety at $\delta 4.37$ to the 7-carbon of the aglycon part at $\delta_{\mathrm{C}} 67.0$. Thus, the position of the glucosyl moiety was confirmed to be at the 7-position and the structure of opuntioside I (2) was characterized as shown.

Compound 3 was shown to have the molecular formula $\mathrm{C}_{8} \mathrm{H}_{10} \mathrm{O}_{4}$ from the molecular ion peak at $m / z 170\left(\mathrm{M}^{+}\right)$in electron impact (EI)-MS and by high-resolution MS measurement. The ${ }^{1} \mathrm{H}-\mathrm{NMR}\left(\mathrm{CD}_{3} \mathrm{OD}\right)$ spectrum of 3 showed signals due to two olefinic protons $[\delta 6.08(\mathrm{~m}, 5-\mathrm{H}), 5.41$ (br s, $3-\mathrm{H})]$ and a methylene bearing an oxygen function $[\delta 4.41$ (s, $\left.\left.7-\mathrm{H}_{2}\right)\right]$. These proton signals were very similar to those of $\mathbf{1}$, expect for the signals due to the 4-substituent, an ethoxyl group, which were observed at $\delta 4.06\left(\mathrm{q}, J=6.9 \mathrm{~Hz}, 8-\mathrm{H}_{2}\right)$ and $\delta 1.41\left(\mathrm{t}, J=6.9 \mathrm{~Hz}, 9-\mathrm{H}_{3}\right)$. The ${ }^{13} \mathrm{C}-\mathrm{NMR}\left(\mathrm{CD}_{3} \mathrm{OD}\right)$ data $^{9)}$ of 3 indicated that it was a pyrone derivative with 4ethoxyl and 6-hydroxymethyl groups. Finally, the structure of 3 was confirmed by the HMBC experiment, which showed long-range correlations between the following protons and carbons: $3-\mathrm{H}$ and 2-C, 4-C; 5- $\mathrm{H}$ and 6-C; 7- $\mathrm{H}_{2}$ and 5-C, 6-C; $8-\mathrm{H}_{2}$ and 4-C. In the difference nuclear Overhauser effect (NOE) experiment on 3, the NOE correlations were observed between the olefinic protons and the ethoxyl group. On the basis of this evidence, 3 was determined to be 4-ethoxyl-6- 


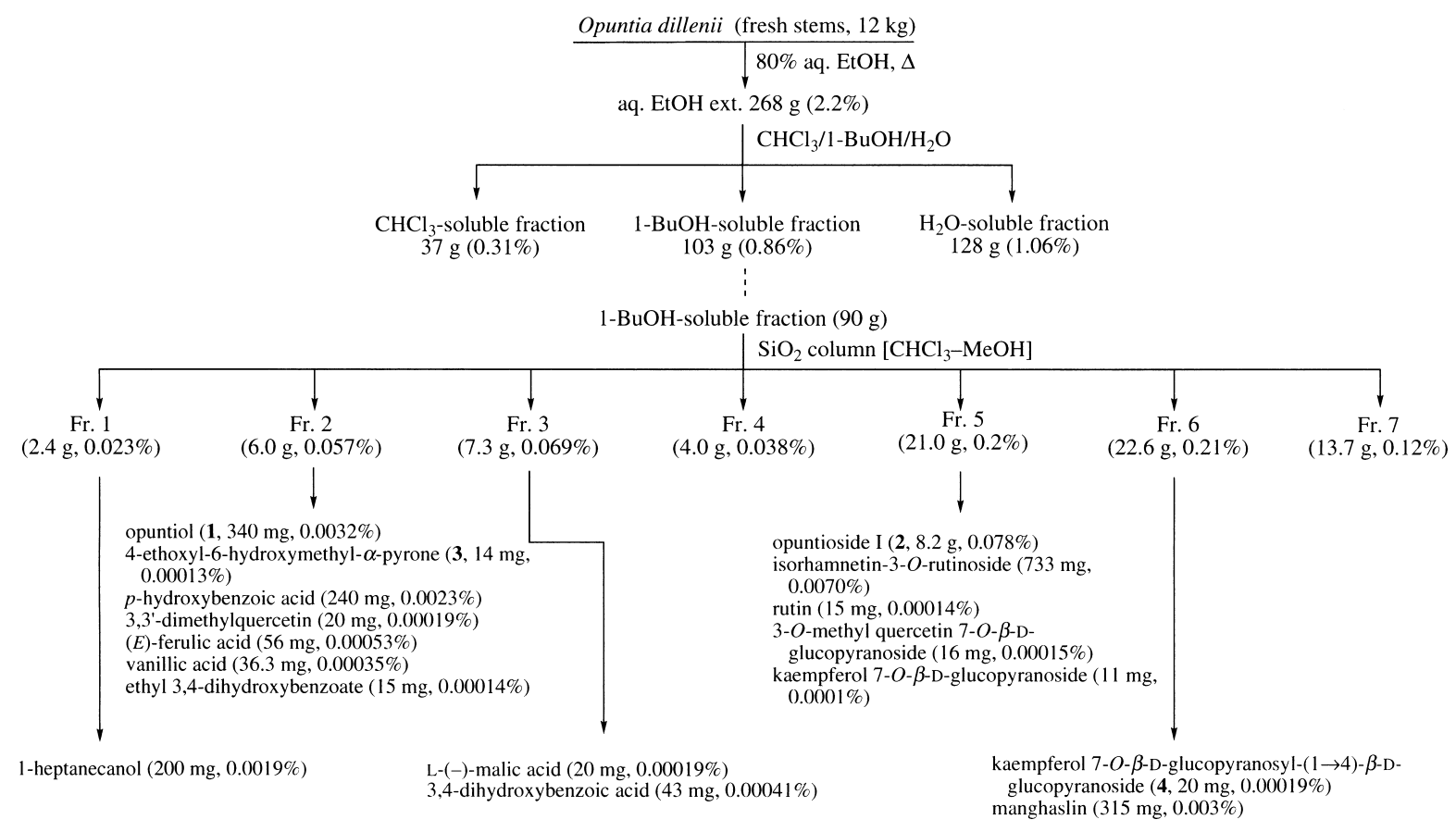

Chart 1<smiles>COc1cc(CO)oc(=O)c1</smiles>

opuntiol (1)<smiles>COc1cc(CO)oc(=O)c1</smiles>

opuntioside I (2) 4-ethoxyl-6-hydroxymethyl- $\alpha$ pyrone (3)

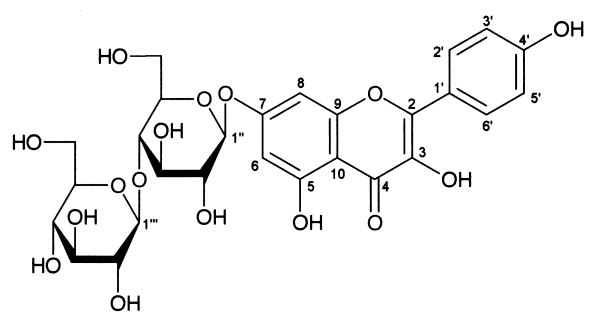

kaempferol 7- $O$ - $\beta$-D-glucopyranosyl-( $1 \rightarrow 4)$ $\beta$-D-glucopyranoside (4)

Chart 2

hydroxymethyl- $\alpha$-pyrone.

Compound $\mathbf{4}$ was isolated as a yellow powder with negative optical rotation $\left([\alpha]_{\mathrm{D}}^{28}-49.0^{\circ}\right)$. The IR spectrum of 4 showed absorption bands ascribable to hydroxyl and carbonyl functions at 3410 and $1655 \mathrm{~cm}^{-1}$. The UV spectrum of 4 showed absorption bands due to a flavonol aglycon at 365 ( $\log \varepsilon$ 4.0), 267 (3.9), and 255 (3.9) nm. The ${ }^{1} \mathrm{H}-\mathrm{NMR}$ (DMSO- $d_{6}$ ) spectrum of $\mathbf{4}$ showed signals assignable to $p$-disubstituted aromatic protons $\left[\delta 8.08\left(\mathrm{~d}, J=9.0 \mathrm{~Hz}, 2^{\prime}, 6^{\prime}-\mathrm{H}\right)\right.$, $\left.6.95\left(\mathrm{~d}, J=9.0 \mathrm{~Hz}, 3^{\prime}, 5^{\prime}-\mathrm{H}\right)\right], m$-coupled aromatic protons $[\delta$ $6.82(\mathrm{~d}, J=2.0 \mathrm{~Hz}, 6-\mathrm{H}), 6.45(\mathrm{~d}, J=2.0 \mathrm{~Hz}, 8-\mathrm{H})]$ together with two anomeric protons $\left[\delta 5.18\left(\mathrm{~d}, J=7.5 \mathrm{~Hz}, 1^{\prime \prime}-\mathrm{H}\right), 4.31\right.$ (d, $\left.\left.J=8.0 \mathrm{~Hz}, 1^{\prime \prime \prime}-\mathrm{H}\right)\right]$. These aromatic proton signals of 4 were attributable to the aglycon moiety and were very similar to those of kaempferol. ${ }^{1)}$ Acid hydrolysis of 4 with $1 \mathrm{M} \mathrm{HCl}$ gave kaempferol and D-glucose. ${ }^{10)}$ Comparison of the ${ }^{13} \mathrm{C}$ -
Table 1. ${ }^{13} \mathrm{C}-\mathrm{NMR}$ Data for Opuntiol (1), Opuntioside I (2), and 4Ethoxyl-6-hydroxymethyl- $\alpha$-pyrone (3)

\begin{tabular}{rrrr}
\hline \hline & \multicolumn{1}{c}{$\mathbf{1}$} & \multicolumn{1}{c}{$\mathbf{2}$} & \multicolumn{1}{c}{$\mathbf{3}$} \\
\hline C-2 & 173.5 & 173.3 & 170.2 \\
C-3 & 88.6 & 89.0 & 88.5 \\
C-4 & 166.8 & 166.6 & 164.2 \\
C-5 & 99.9 & 101.6 & 99.2 \\
C-6 & 166.3 & 162.6 & 163.0 \\
C-7 & 61.1 & 67.0 & 64.7 \\
C-8 & 56.9 & 57.0 & 61.0 \\
C-9 & & & 14.0 \\
C-1 & & 103.8 & \\
C-2 & & 74.8 & \\
C-3 $^{\prime}$ & & 78.0 & \\
C-4 $^{\prime}$ & & 71.4 & \\
C-5 $^{\prime}$ & & 77.8 & \\
C-6 $^{\prime}$ & & 62.6 & \\
\hline
\end{tabular}

Measured in $\mathrm{CD}_{3} \mathrm{OD}$ in $68 \mathrm{MHz}$

NMR data for $\mathbf{4}$ with those for kaempferol and D-glucose revealed two glycosidation shifts around the 7 and 4 "-position of 4 . The oligoglycoside structure of $\mathbf{4}$ was confirmed on the basis of HMBC experiment, which showed long-range correlations between the 1 '"-proton and 4 "-carbon and between the 1 -proton and 7-carbon. Consequently, the structure of $\mathbf{4}$ was determined as kaempferol $7-O$ - $\beta$-D-glucopyranosyl-( $1 \rightarrow 4$ )$\beta$-D-glucopyranoside.

The aqueous ethanol extract and the isolated compounds were evaluated for their 1,1-diphenyl-2-picrylhydrazyl (DPPH) radical scavenging effect. The results are shown in Table 2. In the present study, DPPH radical scavenging activities of the $3^{\prime}, 4^{\prime}$-dihydroxyl substituted flavonoids (such as quercetin) were stronger than those of the $4^{\prime}$-hydroxyl substitutes (such as kaempferol). When the 3-hydroxyl group was substituted by other groups, the activity seemed to be reduced, while the 7-hydroxyl substitutes could increase the ac- 
Table 2. DPPH Radical and $\mathrm{O}_{2}^{-}$Scavenging Activities of the Ethanolic Extract and Isolated Compounds

\begin{tabular}{lcc}
\hline \hline & $\begin{array}{c}\mathrm{DPPH} \\
\text { radical } \\
\mathrm{SC}_{50}\end{array}$ & $\begin{array}{c}\text { Formazan } \\
\text { formation } \\
\mathrm{IC}_{50}\end{array}$ \\
\hline Aq. EtOH ext. & $48 \mu \mathrm{g} / \mathrm{ml}$ & - \\
Opuntiol (1) & $>100 \mu \mathrm{M}$ & $>100 \mu \mathrm{M}$ \\
Opuntioside I (2) & $>100 \mu \mathrm{M}$ & $>100 \mu \mathrm{M}$ \\
4-Ethoxyl-6-hydroxymethyl- $\alpha$-pyrone (3) & $>100 \mu \mathrm{M}$ & $>100 \mu \mathrm{M}$ \\
Kaempferol 7- $O$ - $\beta$-D-glucopyranosyl- & $13 \mu \mathrm{M}$ & $24 \mu \mathrm{M}$ \\
$\quad(1 \rightarrow 4)-\beta$-D-glucopyranoside (4) & & \\
Rutin & $4.3 \mu \mathrm{M}$ & $15 \mu \mathrm{M}$ \\
3-O-Methyl quercetin 7-O- $\beta$-D- & $6.1 \mu \mathrm{M}$ & $3.9 \mu \mathrm{M}$ \\
$\quad$ glucopyranoside & & \\
Kaempferol 7-O- $\beta$-D-glucopyranoside & $12 \mu \mathrm{M}$ & $32 \mu \mathrm{M}$ \\
Kaempferol & $10 \mu \mathrm{M}$ & $11 \mu \mathrm{M}$ \\
3-O-Methyl quercetin & $6.0 \mu \mathrm{M}$ & $11 \mu \mathrm{M}$ \\
Quercetin & $3.3 \mu \mathrm{M}$ & $72 \mu \mathrm{M}$ \\
Manghaslin & $13 \mu \mathrm{M}$ & $3.9 \mu \mathrm{M}$ \\
Vanillic acid & $60 \mu \mathrm{M}$ & $>100 \mu \mathrm{M}$ \\
3,4-Dihydroxybenzoic acid & $11 \mu \mathrm{M}$ & $7.2 \mu \mathrm{M}$ \\
Ethyl 3,4-dihydroxybenzoate & $4.9 \mu \mathrm{M}$ & $11 \mu \mathrm{M}$ \\
(E)-Ferulic acid & $15 \mu \mathrm{M}$ & $>100 \mu \mathrm{M}$ \\
\hline
\end{tabular}

tivity in some experiments. The effect of flavonoids on superoxide anion radical exhibited a different rule from that of DPPH radical: the effect of the $4^{\prime}$-hydroxyl substituted flavonoids (such as kaempferol) is higher than that of the $3^{\prime}, 4^{\prime}$-dihydroxyl substitute (such as quercetin) and the 3methoxy substitutes (such as 3-O-methyl quercetin) could increase the activity greatly.

\section{Experimental}

The following instruments were used to obtain physical data: specific rotations, Horiba SEPA-300 digital polarimeter $(l=5 \mathrm{~cm})$; UV spectra, Shimadzu UV-1200 spectrometer; IR spectra, Shimadzu FTIR-8100 spectrometer; FAB-MS and high-resolution FAB-MS, EI-MS and high-resolution EIMS, JMS-SX 102A mass spectrometer; ${ }^{1} \mathrm{H}-\mathrm{NMR}$ spectra, JEOL EX-270 $(270 \mathrm{MHz}) ;{ }^{13} \mathrm{C}-\mathrm{NMR}$ spectra, JEOL EX-270 $(68 \mathrm{MHz})$ spectrometer with tetramethylsilane as an internal standard; HPLC, Shimadzu LC-10AS chromatograph

The following experimental conditions were used for chromatography: normal-phase column chromatography, Silica gel BW-200 (Fuji Silysia Chemical, Ltd., 150-350 mesh), Cosmosil $75 \mathrm{C}_{18}$-OPN (Nacalai Tesque Co., Ltd., $75 \mu \mathrm{m}$ ); TLC, pre-coated TLC plates with Silica gel $60 \mathrm{~F}_{254}$ (Merck, $0.25 \mathrm{~mm}$ ) (normal-phase) and Silica gel RP-18 $\mathrm{F}_{254}$ (Merck, $0.25 \mathrm{~mm}$ ) (reversed-phase); HPTLC, pre-coated TLC plates with Silica gel RP-18 $\mathrm{WF}_{254}$ (Merck, $0.25 \mathrm{~mm}$ ) (reversed-phase). Detection was done by spraying $1 \% \mathrm{Ce}\left(\mathrm{SO}_{4}\right)_{2}-10 \%$ aqueous $\mathrm{H}_{2} \mathrm{SO}_{4}$, followed by heating.

Bioassay Reagents: xanthine oxidase and nitro blue tetrazolium chloride (NBT) were purchased form Wako Pure Chemical Industries.

Extraction and Isolation The fresh stems of Opuntia dillenii $(12.0 \mathrm{~kg}$, collected from Hainan province of China) were finely minced and extracted with $80 \%$ aqueous EtOH under reflux. Evaporation of the solvent under reduced pressure gave the EtOH extract $(268 \mathrm{~g})$. This extract was partitioned into a $\mathrm{CHCl}_{3}$ and $\mathrm{H}_{2} \mathrm{O}$ mixture, and then extracted with saturated aqueous 1$\mathrm{BuOH}$. Removal of the solvent under reduced pressure from the $\mathrm{CHCl}_{3-}, 1$ $\mathrm{BuOH}-$ and $\mathrm{H}_{2} \mathrm{O}$-soluble fractions yielded $37 \mathrm{~g}, 103 \mathrm{~g}$ and $128 \mathrm{~g}$ of residues, respectively. The $1-\mathrm{BuOH}$-soluble fraction $(90 \mathrm{~g})$ was subjected to repeated normal-phase silica gel column $\left[1.2 \mathrm{~kg}, \mathrm{CHCl}_{3}-\mathrm{MeOH}(10: 1 \rightarrow 5: 1, \mathrm{v} / \mathrm{v}) \rightarrow\right.$ $\mathrm{CHCl}_{3}-\mathrm{MeOH}-\mathrm{H}_{2} \mathrm{O} \quad(10: 3: 1$, lower layer $\rightarrow 7: 3: 1$, lower layer $\rightarrow 6: 4: 1$, $\mathrm{v} / \mathrm{v}) \rightarrow \mathrm{MeOH}]$ to give seven fractions. Fraction 1 was further separated by normal-phase silica gel column chromatography $[30 \mathrm{~g}, n$-hexane-AcOEt $(10: 1 \rightarrow 5: 1, \mathrm{v} / \mathrm{v})]$ to give 1 -heptanecanol $(200 \mathrm{mg}, 0.0019 \%)$. Fraction 2 was separated by reversed-phase silica gel column $\left[120 \mathrm{~g}, \mathrm{MeOH}-\mathrm{H}_{2} \mathrm{O}\right.$ $(30: 70 \rightarrow 40: 60 \rightarrow 60: 40 \rightarrow 80: 20, \quad \mathrm{v} / \mathrm{v}) \rightarrow \mathrm{MeOH}]$ and repeated HPLC [YMC-Pack ODS-A $(250 \times 20 \mathrm{~mm}$ i.d., YMC Co., Ltd. $), \mathrm{MeOH}-\mathrm{H}_{2} \mathrm{O}$ $(30: 70,45: 55,60: 40, v / v)]$ to give 4-ethoxyl-6-hydroxymethyl- $\alpha$-pyrone (3, $14 \mathrm{mg}, 0.00013 \%)$ and six other known compounds as shown in Chart 1.
Fraction 3 was separated by reversed-phase silica gel column $[180 \mathrm{~g}$, $\left.\mathrm{MeOH}-\mathrm{H}_{2} \mathrm{O}(30: 70 \rightarrow 40: 60 \rightarrow 60: 40 \rightarrow 80: 20, \mathrm{v} / \mathrm{v}) \rightarrow \mathrm{MeOH}\right]$ and repeated HPLC $\left[\mathrm{MeOH}-\mathrm{H}_{2} \mathrm{O}(20: 80, \mathrm{v} / \mathrm{v})\right]$ to give two known compounds. Fraction 5 was separated by reversed-phase silica gel column $\left[400 \mathrm{~g}, \mathrm{MeOH}-\mathrm{H}_{2} \mathrm{O}\right.$ $(10: 90 \rightarrow 30: 70 \rightarrow 40: 60 \rightarrow 60: 40 \rightarrow 80: 20, \mathrm{v} / \mathrm{v}) \rightarrow \mathrm{MeOH}]$ to give opuntioside I $(2,8.2 \mathrm{~g}, 0.078 \%)$, then repeated HPLC [MeOH- $\left.\mathrm{H}_{2} \mathrm{O}(50: 50, \mathrm{v} / \mathrm{v})\right]$ and Sephadex-LH20 [20 g, MeOH] column chromatography led to the isolation of four known flavonol glycosides. Fraction 6 was separated by reversed-phase silica gel column $\left[450 \mathrm{~g}, \mathrm{MeOH}-\mathrm{H}_{2} \mathrm{O}(10: 90 \rightarrow 30: 70 \rightarrow 40\right.$ : $60 \rightarrow 60: 40 \rightarrow 80: 20, \mathrm{v} / \mathrm{v}) \rightarrow \mathrm{MeOH}$, repeated HPLC $\left[\mathrm{MeOH}-\mathrm{H}_{2} \mathrm{O}(50: 50\right.$, $\mathrm{v} / \mathrm{v})]$ and Sephadex-LH20 $[20 \mathrm{~g}, \mathrm{MeOH}]$ column chromatography to give kaempferol 7-O- $\beta$-D-glucopyranosyl-(1 $\rightarrow 4)-\beta$-D-glucopyranoside $(4,20 \mathrm{mg}$, $0.00019 \%)$ and manghaslin ( $315 \mathrm{mg}, 0.003 \%)$. Eight known compounds, $p$ hydroxybenzoic acid, L-(-)-malic acid, $(E)$-ferulic acid, 1-heptanecanol, vanillic acid, rutin, ethyl 3,4-dihydroxybenzoate, and 3,4-dihydroxy benzoic acid were identified by comparison of TLC behavior, ${ }^{1} \mathrm{H}-$ and ${ }^{13} \mathrm{C}-\mathrm{NMR}$ spectra with those of authentic samples, while other known compounds, opuntiol, 3,3'-dimethylquercetin, isorhamnetin-3-O-rutinoside, 3-O-methyl quercetin 7-O- $\beta$-D-glucopyranoside, kaempferol 7-O- $\beta$-D-glucopyranoside, and manghaslin were identified by comparison of their spectral data with reported values. ${ }^{2-8)}$

Opuntioside I (2): Colorless fine crystals, mp $128.2-131.3^{\circ} \mathrm{C},[\alpha]_{\mathrm{D}}^{26}$ $-42.0^{\circ}(c=1.0, \mathrm{MeOH})$. High-resolution FAB-MS: Calcd for $\mathrm{C}_{13} \mathrm{H}_{19} \mathrm{O}_{9}$ $(\mathrm{M}+\mathrm{H})^{+}: 319.1029$. Found: 391.1034 . UV $(\mathrm{MeOH}) \lambda_{\max } 279 \mathrm{~nm}(\log \varepsilon 3.8)$, IR (KBr): 3367, 2897, 1703, 1572, $1051 \mathrm{~cm}^{-1} .{ }^{1} \mathrm{H}-\mathrm{NMR}\left(\mathrm{CD}_{3} \mathrm{OD}\right) \delta: 6.38$ $(1 \mathrm{H}, \mathrm{m}, 5-\mathrm{H}), 5.57(1 \mathrm{H}$, br s, $3-\mathrm{H}), 4.48,4.62(1 \mathrm{H}$ each, both d, $J=14.8 \mathrm{~Hz}$, $\left.7-\mathrm{H}_{2}\right), 4.37\left(1 \mathrm{H}, \mathrm{d}, J=7.5 \mathrm{~Hz}, 1^{\prime}-\mathrm{H}\right), 3.88\left(3 \mathrm{H}, \mathrm{s}, 8-\mathrm{H}_{3}\right) .{ }^{13} \mathrm{C}-\mathrm{NMR}\left(\mathrm{CD}_{3} \mathrm{OD}\right)$ $\delta_{\mathrm{C}}$ : given in Table 1. Positive ion FAB-MS: $m / z 319(\mathrm{M}+\mathrm{H})^{+}$.

4-Ethoxyl-6-hydroxymethyl- $\alpha$-pyrone (3): Colorless fine crystals, $\mathrm{mp}$ 94.5- $96.8^{\circ} \mathrm{C}$. High-resolution EI-MS: Calcd for $\mathrm{C}_{8} \mathrm{H}_{10} \mathrm{O}_{4}(\mathrm{M})^{+}$: 170.0579 . Found: 170.0573 . UV (MeOH) $\lambda_{\max } 280 \mathrm{~nm}(\log \varepsilon 3.8)$, IR (KBr): 3352 , $2988,1703,1646,1570,1258,1086,1036 \mathrm{~cm}^{-1} .{ }^{1} \mathrm{H}-\mathrm{NMR}\left(\mathrm{CD}_{3} \mathrm{OD}\right) \delta: 6.08$ $(1 \mathrm{H}, \mathrm{m}, 5-\mathrm{H}), 5.41\left(1 \mathrm{H}\right.$, br s, 3-H), $4.41\left(2 \mathrm{H}, \mathrm{s}, 7-\mathrm{H}_{2}\right), 4.06(2 \mathrm{H}, \mathrm{q}$, $\left.J=6.9 \mathrm{~Hz}, 8-\mathrm{H}_{2}\right), 1.41\left(3 \mathrm{H}, \mathrm{t}, J=6.9 \mathrm{~Hz}, 9-\mathrm{H}_{3}\right) .{ }^{13} \mathrm{C}-\mathrm{NMR}\left(\mathrm{CD}_{3} \mathrm{OD}\right) \delta_{\mathrm{C}}$ : given in Table 1. EI-MS (\%): $m / z 170\left(\mathrm{M}^{+}, 31\right), 139(100)$.

Kaempferol 7- $O-\beta$-D-Glucopyranosyl-( $(1 \rightarrow 4)-\beta$-D-glucopyranoside (4): A yellow powder, $[\alpha]_{\mathrm{D}}^{28}-49.0^{\circ}(c=0.5, \mathrm{MeOH})$. High-resolution FAB-MS: Calcd for $\mathrm{C}_{27} \mathrm{H}_{30} \mathrm{O}_{16} \mathrm{Na}(\mathrm{M}+\mathrm{Na})^{+}$: 633.1432. Found: 633.1422. UV $(\mathrm{MeOH}) \lambda_{\max } 365 \mathrm{~nm}(\log \varepsilon 4.0), 267 \mathrm{~nm}(\log \varepsilon 3.9), 255 \mathrm{~nm}(\log \varepsilon 3.9)$, IR (KBr): $3410,1655,1597,1499,1310,1179,1075,1024,992 \mathrm{~cm}^{-1} .{ }^{1} \mathrm{H}-$ NMR (DMSO- $\left.d_{6}\right) \delta: 12.51(1 \mathrm{H}, \mathrm{s}, 5-\mathrm{OH}), 8.08\left(2 \mathrm{H}, \mathrm{d}, J=9.0 \mathrm{~Hz}, 2^{\prime}, 6^{\prime}-\mathrm{H}\right)$, $6.95\left(2 \mathrm{H}, \mathrm{d}, J=9.0 \mathrm{~Hz}, 3^{\prime}, 5^{\prime}-\mathrm{H}\right), 6.82(1 \mathrm{H}, \mathrm{d}, J=2.0 \mathrm{~Hz}, 6-\mathrm{H}), 6.45(1 \mathrm{H}, \mathrm{d}$, $J=2.0 \mathrm{~Hz}, 8-\mathrm{H}), 5.18\left(1 \mathrm{H}, \mathrm{d}, J=7.5 \mathrm{~Hz}, 1^{\prime \prime}-\mathrm{H}\right), 4.31\left(1 \mathrm{H}, \mathrm{d}, J=8.0 \mathrm{~Hz}, 1^{\prime \prime \prime}-\right.$ H). ${ }^{13} \mathrm{C}-\mathrm{NMR}$ (DMSO- $d_{6}$ ) $\delta_{\mathrm{C}}: 176.0$ (4-C), 162.4 (7-C), 160.3 (9-C), 159.3 (4'-C), 155.6 (5-C), 147.5 (2-C), 135.9 (3-C), 129.6 (2', 6'-C), $121.4\left(1^{\prime}-\mathrm{C}\right)$, 115.4 (3', 5'-C), 104.6 (10-C), 103.0 (1'"-C), 99.2 (1"'-C), 98.6 (8-C), 94.3 (6-C), 79.6 (4"-C), 76.7 (5'"-C), 76.4 (3"'--C), 75.0 (5"-C), 74.7 (3"-C), 73.2 (2"'-C), 72.7 (2"-C), 69.9 (4'"-C), 60.9 (6"'-C), 59.8 (6"-C). Positive-ion FABMS: $m / z 611(\mathrm{M}+\mathrm{H})^{+}$

Enzymatic Hydrolysis of $\mathbf{2}$ with $\boldsymbol{\beta}$-Glucosidase A solution of $\mathbf{2}$ $(10 \mathrm{mg})$ in $0.2 \mathrm{M}$ acetate buffer $(\mathrm{pH} 4.4,10 \mathrm{ml})$ was treated with $\beta$-glucosidase (Oriental Yeast Co., Japan, $6.0 \mathrm{mg}$ ) and the reaction mixture was stirred at $38{ }^{\circ} \mathrm{C}$ for $12 \mathrm{~h}$. The mixture was then poured into $\mathrm{H}_{2} \mathrm{O}$ and the whole was extracted with AcOEt. The AcOEt extract was washed with saturated aqueous $\mathrm{NaHCO}_{3}$ and brine, then dried over $\mathrm{MgSO}_{4}$ and filtered. After removal of the solvent under reduced pressure, the residue was purified by silica gel column chromatography $\left(0.5 \mathrm{~g}, \mathrm{CHCl}_{3}-\mathrm{MeOH}=20: 1\right)$ to give $\mathbf{1}(4.3 \mathrm{mg})$, which was identified by comparison of the physical data with an authentic opuntiol.

Acid Hydrolysis of 2 A solution of 2 (10 mg) in $1 \mathrm{~m}$ aqueous $\mathrm{HCl}-1,4-$ dioxane $(1: 1, \mathrm{v} / \mathrm{v}, 2 \mathrm{ml})$ was heated at $95^{\circ} \mathrm{C}$ under reflux for $3 \mathrm{~h}$. After cooling, the reaction mixture was neutralized with IRA-400 $\left(\mathrm{OH}^{-}\right.$form $)$and the residue was removed by filtration. After removal of the solvent from the filtrate in vacuo, the $\mathrm{H}_{2} \mathrm{O}$ eluate was concentrated and the residue was purified by silica gel column chromatography $\left(0.5 \mathrm{~g}, \mathrm{CHCl}_{3}-\mathrm{MeOH}=20: 1\right.$ to $\left.1: 1\right)$ to give a sugar fraction $(4.3 \mathrm{mg})$. The sugar fraction was dissolved in $\mathrm{H}_{2} \mathrm{O}$ and analyzed by HPLC under the following conditions: column, Kaseisorb LC NH$-60-5,250 \times 4.6 \mathrm{~mm}$ i.d. (Tokyo Kasei Kogyo Co., Ltd.); solvent, $\mathrm{MeCN}-\mathrm{H}_{2} \mathrm{O}(3: 1)$; flow rate, $0.8 \mathrm{ml} / \mathrm{min}$; detection, optical rotation. Identification of D-glucose present in the sugar fraction was carried out by comparison of its retention times $\left(t_{\mathrm{R}}=12.3 \mathrm{~min}\right.$ ) and optical rotation (positive optical rotation) with those of authentic sample.

Acid Hydrolysis of 4 Compound 4 (5 mg) was subjected to acid hydrolysis as described for $\mathbf{2}$ to give kaempferol $(1.6 \mathrm{mg})$ and a sugar fraction 
(1.8 mg). HPLC analysis of the sugar fraction under the same conditions as in the case of that of $\mathbf{2}$ showed the presence of D-glucose (positive optical rotation).

DPPH Radical Scavenging Activity DPPH radical scavenging activities of the EtOH extract and compounds were investigated according to the method of Uchiyama et al. ${ }^{11)}$ Briefly, a solution of the test compound in EtOH $(1.0 \mathrm{ml})$, acetate buffer $(\mathrm{pH} 5.5,1.0 \mathrm{ml})$ and $200 \mu \mathrm{M}$ DPPH radical in $\mathrm{EtOH}(0.5 \mathrm{ml})$ was incubated at room temperature for $30 \mathrm{~min}$. Reduction of the DPPH radical was measured at $517 \mathrm{~nm}$. Measurements were performed in duplicate, and the concentration required for a $50 \%$ reduction $50 \%$ scavenging concentration, $\mathrm{SC}_{50}$ ) of $40 \mu \mathrm{M} \mathrm{DPPH}$ radical was determined graphically. Results are shown in Table 1.

$\cdot \mathbf{O}_{2}^{-}$Scavenging Activity The improved assay method for superoxide dismutase described by Imanari et al. was used. ${ }^{12)}$ Briefly, a reaction mixture containing $100 \mu \mathrm{m}$ xanthine, $100 \mu \mathrm{m}$ EDTA, $25 \mu \mathrm{M}$ NBT, $0.005 \%$ bovine serum albumin, and $c a .1 .5 \mathrm{mU} / \mathrm{ml}$ xanthine oxidase in $33.3 \mathrm{~mm}$ sodium carbonate buffer ( $\mathrm{pH}$ 10.2) was incubated with or without each test sample for $20 \mathrm{~min}$ at $25^{\circ} \mathrm{C}$ (total volume: $3.0 \mathrm{ml}$ ). After incubation, the solution was mixed with $0.1 \mathrm{ml}$ of $6 \mathrm{mM} \mathrm{CuCl}_{2}$ to stop the reaction. The formazan formation was monitored at $560 \mathrm{~nm}$ and $\mathrm{IC}_{50}$ values for the formazan formation activity were determined.

\section{References and Notes}

1) Qiu Y. K., Yoshikawa M., Li Y. H., Dou D. Q., Pei Y. P., Chen Y. J.,
Journal of Shenyang Pharmaceutical University, 17, 267-268 (2000).

2) Ganguly A. K., Govindachari T. R., Mohamed P. A., Tetrahedron, 21, 93-99 (1965).

3) Telang S. A., Phytochemistry, 12, 2059 (1973).

4) Valesi A. G., Rodriguez E., Velde G. V., Mabry T. J., Phytochemistry, 11, 2821-2826 (1972).

5) Chaurasia N., Wichtl M., Planta Med., 53, 432-434 (1987).

6) Öksüz S., Planta Med., 31, 270-272 (1977).

7) Markham K. R., Ternam B., Stanley R., Geiger H., Mabry T. J., Tetrahedron, 34, 1389-1397 (1978).

8) Sakushima A., Hisada S., Ogihara Y., Nishibe S., Chem. Pharm. Bull., 28, 1219-1223 (1980).

9) The ${ }^{1} \mathrm{H}$ - and ${ }^{13} \mathrm{C}$-NMR spectra were assigned with the aid of homoand hetero-correlation spectroscopy $\left({ }^{1} \mathrm{H}-{ }^{1} \mathrm{H},{ }^{1} \mathrm{H}-{ }^{13} \mathrm{C}\right.$ COSY), distortionless enhancement by polarization transfer (DEPT) and heteronuclear multiple bond connectivity (HMBC).

10) Matsuda H., Nishida N., Yoshikawa M., Chem. Pharm. Bull., 50, $429-431$ (2002).

11) Uchiyama M., Suzuki Y., Fukuzawa K., Yakugaku Zasshi, 88, 678683 (1968).

12) Imanari T., Hirota M., Miyazaki M., Hayakawa K., Tamura Z., Igaku No Ayumi, 101, 496-497 (1977). 